\title{
Dictionary of Linguoculturology Terms as a Solution to the Current Research Problem ${ }^{1}$
}

\author{
Valentina Kulpina \\ Lomonosov Moscow State University \\ Faculty of Foreign Languages and Regional Studies
}

Viktor Tatarinov

Russian Terminology Society RossTerm, Moscow

Received 30 June 2018 • Revised 20 July 2018 • Accepted 22 July 2018

\section{Abstract}

\begin{abstract}
The review is devoted to the dictionary of linguoculturological terms; such type of dictionary is innovative one and presumably is the first dictionary of key terms and concepts of linguoculturology, both in the native and world science. Linguoculturology is considered in the dictionary as a direction which studies the interaction of language and culture as the semiotic systems and at the same time as a single holistic phenomenon. The dictionary consists of 25 terms which constitute the conceptual core of this subject - such as archetype, code of culture, cultural connotation, symbol, stereotype, linguistic worldview etc., and their explanation. The dictionary is the result of research of the basic concepts of this field of knowledge and their distancing from the similar terms and concepts of adjacent linguistic disciplines.
\end{abstract}

Keywords: dictionary, term, concept, linguoculturology, terminology studies.

The authors Dmitry Gudkov and Maria Kovshova in their foreword "From Authors" have pointed out that the dictionary created by them is presumably the first dictionary of key terms and concepts of linguoculturology both in the native and world science. In total, the dictionary contains a detailed explanation of 25 terms which constitute the conceptual core of this subject. On the stage of formation of linguoculturology as a science it is especially important to publish a dictionary of linguocultural terms, which define the content of basic concepts of this subject, including the main term is "linguoculturology".

Linguoculturology is considered as a direction which studies the interaction of language and culture as the semiotic systems and at the same time as a single holistic phenomenon. Linguoculturologist is primarily interested in realisation of culture in the linguistic

\footnotetext{
${ }^{1}$ Rec. ad opus: Словарь лингвокультурологических терминов / Авторы-составители: М. Л. Ковшова, Д. Б. Гудков / Отв. ред. М. Л. Ковшова. Москва: Гнозис, 2017. 192 с. (Maria Kovshova (Executive Editor); Maria Kovshova \& Dmitry Gudkov. Dictionary of Linguoculturological Terms).

(C) Authors. Terms and conditions of Creative Commons Attribution 4.0 International (CC BY 4.0) apply. Correspondence: Valentina Kulpina, Lomonosov Moscow State University, Faculty of Foreign Languages and Regional Studies, Moscow, RUSSIAN FEDERATION. E-mail: vgrkulpina@mail.ru.
} 
structures and in the linguocultural competence of a man. Language is considered to be a creator of the man's mentality. The authors believe that the emergence of linguoculturology at the turn of the previous and current centuries reflects the desire of modern humanitarian knowledge for integrativity in the mainstream of the anthropological paradigm.

Kovshova's preface to the dictionary titled On the principles of creating the Dictionary of linguocultural terms presents linguoculturology as new subject area which is oriented towards man "existing and acting "at the intersection" of such fundamental systems as language, consciousness, culture and communication" (p. 8). The subject, basic concepts, principles and methods of research of linguoculturology as a young science need to be understood. Linguoculturology is methodologically linked with ethnolinguistics which, in its turn, is based on the semantics of culture, ethnopsychology, folk psychology and mythology, and reconstruction of people's psychological representations in their development. The task of linguoculturology is to generalize the achievements of ethnolinguistics "in the range of synchronous cultural-national consciousness and its language presentation” (p. 9).

Kovshova points to the closeness of linguoculturology to such areas as contrastive linguistics and linguistic country studies. However, at this stage, linguoculturology is particularly concerned about "the ethnic logic imprinted in the internal form, semantics and pragmatics of the linguistic sign" (Ibid.). The author considers the cultural function of a language as "an ability of a linguistic sign to contain cultural meanings in its semantics, to translate them into speech, thereby achieving the significance of a model, symbol, stereotype and concept, to be a cultural symbol and to participate in the categorization of the conceptosphere of culture" (Ibid.).

The dictionary is aimed to create a single conceptual and terminological system which is open for a dialogue with various scientific schools and directions, streamlining of terminology and lexicographic presentation of the language of linguoculturology. It is important to note that the lexicographic form of linguoculturology presented in the dictionary is the result of research of the basic concepts of this new field of knowledge and their distancing from the similar terms and concepts of adjacent linguistic disciplines. The dictionary articles have the following structure: the central term is accompanied by its variants in the form of words or phrases; it is followed by a definition, which, in its turn, is followed by a scientific comment containing the quotations from the works of key specialists. As a result we have a kind of concordance of linguoculturology. These quotations represent the zest of the dictionary, its captivating feature, because these carefully selected quotations can be quoted further on in our own works with reference to the dictionary. Quite often these are quotations from the works of authors of the dictionary (who are, by the way, the reputable linguists). The availability of direct citations is extremely convenient for the user, because he can just take these "alive" quotes from the dictionary without performing the complex search. The dictionary contains a material which illustrates the use of terms in the linguistic discourse; main terms have references to the other terms which, in turn, are supplementing the content of a basic term which ensures the interconnection of the terminological system. The dictionary contains also the bibliography which gives a complete picture of its source database.

Let's consider the presentation of some basic terms in the dictionary. One of these terms is the "culture code" which primarily refers to the cultural value content, material and spiritual values, created by a man in the process of mastering the world and expressed in his linguistic picture. Phenomena of culture form the complexes which allow us to store the vital experience. And thus the cultural code ensures the preservation and functioning of culture, the basis for its development and continuity. Language part of the culture code is formed by the signs of language as the exponents of cultural meanings coded in these signs. Notion of the culture code refers to impressions of world picture of a certain society (ideas of natural objects, artifacts, phenomena, events, mento-facts...). Substratum of the culture code is formed by its texts. Culture code can be understood as a grid or a matrix with which the culture covers the surrounding world, 
splits it, categorizes it, structures it and evaluates it as a coordinate system which contains and sets the standards of culture.

Codes of culture appear in the dictionary article as a normative-value system which is historically formed, which organizes and structures the ethno-cultural and linguistic consciousness and manifests itself in the processes of categorization of the world. Dictionary contains a quotation of Yu. M. Lotman in which the cultural code is broadly considered as a way of preserving and transmitting of information, and as a type of cultural memory.

Extensive dictionary article Language picture of the world is focused on the fact that "in the human mind the real world is displayed to the extent it is reflected in the language and each language reflects the real world in its own way..." (Ibid., p. 144). Linguistic picture of the world can be considered as a set of ideas about the world and the certain ways of its conceptualisation which was historically formed in the ordinary consciousness of a given language collective: "Cognitive linguistics defines the linguistic picture of the world as a meaning of conceptual picture of the world in the language, i.e. the world perceived by consciousness and existing in the reduced and simplified representation of the entire sum of naive ideas about the world (E.S. Kubryakova, V.Z. Demyankov)" (p. 144).

Term Stereotype is interpreted in the dictionary as a sign of language and culture behind which there is a stable, minimised and invariant view of the subject or situation which is nationally and culturally conduced. Stereotype can be designated as a mental image, a certain collective standard representation of a typical fragment of the world picture resulting from reflection of reality in the human mind and synthesising the typical situations and properties in itself. Stereotype includes the most typical, most important features of an object the set of which is limited. Stereotype views are fixed in phraseologisms. Thus, the phraseologism "mother's darling" (sissy boy) reflects the idea of a weak-willed, non-initiative man who is fully dependent on a woman, most often his mother. Stereotypes strengthen the culture; they testify its integrity and stability. Stereotypes of communication and behaviour quite often represent the nationally specific models. Development and translation of communication stereotypes are associated with the processes of socialization of the individual. A man develops as a member of society; he assimilates and develops some stereotypes - stereotypes of communication, ideas about something.

Going beyond the established stereotypes to another culture and intercultural space can cause violation and breakdown of stereotypes and, finally, communication disorders which are very distinctly manifested when learning a foreign language and another culture, as they are leading to a violation of ethno-specific socio-cultural norms of behaviour. Sometimes a foreigner understands each word of an utterance; however, he is unable to grasp the general meaning of this utterance. Thus, within each language the stereotype images of animals are formed and then they are transferred to human beings. E.g. on the basis of a stereotype "a bird is stupid", the idiom "birdbrain" was formed which characterizes a stupid person.

Symbol is presented in the dictionary as a sign of culture which replaces the realities being used instead of them and representing the cultural meaning. At the same time the symbol represents a stable image. Image and meaning of a symbol are interrelated while a symbol is a kind of text which is produced and reproduced. Symbols of culture as signs of culture in the semiotic system have a different status in which the objects and things are primary, but the words denoting symbols become their representatives and signs. Symbol can replace not only an object, but also an idea. We are talking about symbols when a certain reality acquires a cultural meaning for us, when its image acquires a special value, and its verbal sign also acts as a symbol. 
A number of complex concepts are explained in the dictionary from the point of view of "involvement" in linguoculturology, in particular, the concept "cultural connotation". It is noted that "Linguistics defines the connotation as an additional value which arises when an expression is used in a certain context". Connotation is regularly acting as a part of a meaning and "is possible in case the native speaker has different types of cultural knowledge" (p. 65).

In describing such a notion as "culture settings" the attention is drawn to their manifestations in the form of unwritten rules of culture, to the connection of cultural attitudes with social and spiritual values: "Cultural settings are conditioned by a human's awareness of his belonging to a particular culture. Culture settings are manifested in the way of life, in behaviour, in cognitive-practical and creative activity, in life philosophy, embodied in art mythological, literary and artistic, etc." (p. 131).

And finally, let us consider how the problematic of values connected with the questions of the value system, value picture of the world, value orientations, perceptions and moral ideals is reflected in the dictionary. Values appear as the cultivated notions of significance of the world and its manifestations in the human life. Notion of value is based on the consideration that physical objects acquire value when placed in the social relations of people and are evaluated from the point of view of their qualities and usefulness for the society. Values are the highest benchmarks of culture which are occupying a significant place in the structure of the language personality and its preferences. Each nation has its range of values from the highest to the lowest. Values are stable; however, they can change. The language person looks at the world through the prism of categories of his native language. Certain type of culture is formed on the basis of totality of values associated with the native language. A man defines the values according to the value scale of norms, standards and stereotypes; however, he is unable to avoid subjectivism, even with the generally accepted canons. Culture space is full of evaluations. Values can be described for a certain period and for a certain group of people.

The dictionary contains many interesting, curious, important and intriguing issues for each modern linguist, e.g. such dictionary articles as Conceptual sphere of culture, Cultural information, Cultural-linguistic personality, Linguoculture, Precedent situation, Precedent phenomenon, etc. From the bottom of our hearts we recommend the dictionary to linguists, not only for work, but also for their "extracurricular reading", for the soul and expanding the lingvocultural horizon.

It is obvious that the work on the dictionary will be continued to a certain extent, so let us make some assumptions concerning the further updating of these studies. It is necessary to define the clear criteria for establishing the boundaries and limits of the terminological system of linguoculturology: the unconditional acceptance of the postulate of interdisciplinarity leads to the erosion of the conceptual-terminological apparatus of linguoculturology. It is hard to believe in the successful differentiation of such general scientific terms as "archetype", "culture", and the other terms within linguoculturology. The failure of conceptual-terminological stratification in the investigated terminological system has caused the undifferentiated lexical representation in the dictionary of linguistic units, functioning in linguoculturology. General scientific terms should remain outside the boundaries of the sectoral dictionary. Whatever is the conceptual extension of the general scientific term, it cannot turn it into the sectoral term. General scientific word enters this sectoral terminology system hyponymously and being modified in a natural way, e.g. cultural connotation.

In continuation of this topic, it is necessary to wait for a while with reasoning on the unification of terminology of linguoculturology. Firstly, the goals of unification are to be clarified. Secondly, the terms used in linguoculturology are not yet fully collected, lexicographically processed and conceptually realized. 
It is necessary to increase sufficiently the number of terms described in the dictionary. A careful selection of terms from case studies on linguoculturology is required - the dictionary is to be objective.

We conclude our review with a wish and hope to see the expanded and linguocultural version of the dictionary in the near future.

\section{Acknowledgements}

This research did not receive any specific grant from funding agencies in the public commercial, or not-for-profit sectors.

The authors declare no competing interests.

\section{References}

Ковшова М. Л. (Отв. ред.). Ковшова М. Л., Гудков Д. Б. (2017). Словарь лингвокультурологических терминов [Maria Kovshova (Executive Editor), M. L. Kovshova \& D. B. Gudkov: Dictionary of Linguoculturological Terms]. Москва: Гнозис. 
V. Kulpina \& V. Tatarinov - Dictionary of Linguoculturology Terms as a Solution to...

C O A $\mathbf{s}$ 